\title{
NOVĚ IDENTIFIKOVANÁ NOVOVĚKÁ POLNÍ OPEVNĚNÍ NA LHENICKU (OKRES PRACHATICE)
}

\author{
MONIKA KONRÁDOVÁ - VÁCLAV VONDROVSKÝ - MARTIN PTÁK - JAN JOHN - JAN \\ KOCINA
}

\begin{abstract}
Abstrakt: Přispěvek seznamuje s dosud neznámými polními fortifikacemi z obdobi třicetileté války, které byly zachyceny na katastrech obcí Vadkov a Třešňový Újezdec spadajicich do prachatického okresu. Jedná se o dva zachované úseky liniového opevněni s redany, jež zaujímaji strategickou polohu v místech s nižš průchodnosti Lhenickou brázdou. Patrná je také vazba opevnění na komunikace dochované ve formě úvozových cest. V príspěvku jsou shrnuty dosavadní výsledky nedestruktivního průzkumu i prostorově omezené sondáže v mistě jednoho z redanů. Výpovéd' historických pramenů pak umožňuje přesnějši dataci a zasazení do kontextu válečných operací v počátečním obdobi třicetileté války na jihu Čech.
\end{abstract}

Klíčová slova: polní opevnění - třicetiletá válka - nedestruktivní průzkum - Vadkov - Třešňový Újezdec.

\section{Newly Detected Modern-Age Field Fortifications in the Lhenice Region (Prachatice District)}

Abstract: This article describes field fortifications from the period of the Thirty Years' War detected in the cadastral zones of the Vadkov and Třěňnový Újezdec villages in the Prachatice district. The research focused on two preserved sections of a line fortification with redans occupying a strategic position in places where the Lhenická brázda basin is the least penetrable. The fortification was linked to communications preserved in the form of hollow ways. The contribution sums up the results of non-destructive trenching and test trenching on the site of one of the redans. The dating and placement of the fortification in the context of military campaigns in the early phase of the Thirty Years' War in southern Bohemia are specified by historical sources.

Key words: field fortifications - Thirty Years' War-non-destructive trenching-Vadkov-Třešňový Újezdec.

\section{1 Úvod}

Polní opevnění a vojenské tábory patří k důležitým pramenům pro poznání konfliktů raného novověku. Přestože se při rekonstrukci válečných událostí tohoto období lze oprrít o často detailní popis písemných pramenů, má průzkum polních opevnění či jiných hmotných dokladů svou nezastupitelnou roli zvláště v místech, kde písemné prameny chybí, nejsou dostatečně podrobné či jsou nepřesné a tendenční. Jak lze demonstrovat i na tomto př́spěvku, pramenná základna není v případě polních opevnění a táborů ještě vyčerpána a stále dochází k identifikaci nových a dosud neznámých lokalit, a to i přesto, že v jižních Čechách již byla popsána řada lokalit tohoto typu, obzvláště na území Šumavy (Beneš et al. 1995; Fröhlich 1986; 1990; 2000; Kubů-Zavřel 1988).

Předkládaný článek představuje výsledky terénního průzkumu a drobné sondáže v prostoru nově identifikovaných polních opevnění na katastrálních územích Vadkov a Třešňový Újezdec, okres Prachatice (obr. 1).

\section{Metodika}

Prezentovaná opevnění byla objevena pracovníky Archeologického ústavu FF JU v rámci projektu Linecká stezka. Jeho primárním cílem byla prezentace archeologických památek veřejnosti, ale důležitou součástí byla též prospekce s cílem ověřit v terénu stav známých památek a identifikovat památky nové (shrnutí viz Vondrovský et al. 2015). Zájmový prostor byl z větší části sledován pomocí dat leteckého laserového skenování, avšak vodítkem pro průzkum právě v okolí Vadkova a Třešňového Újezdce byly pomístní názvy Na Šancích a Šance, které indikovaly prŕítomnost fortifikací. ${ }^{1}$ Opevnění bylo po prvotní lokalizaci v terénu přesně zaměřeno po-

1 Obě zmíněná toponyma jsou na Základní mapě ČR 1: 10000 zanesena přibližně 400 metrů od skutečné polohy opevnění, což na počátku prospekci ztěžovalo. 


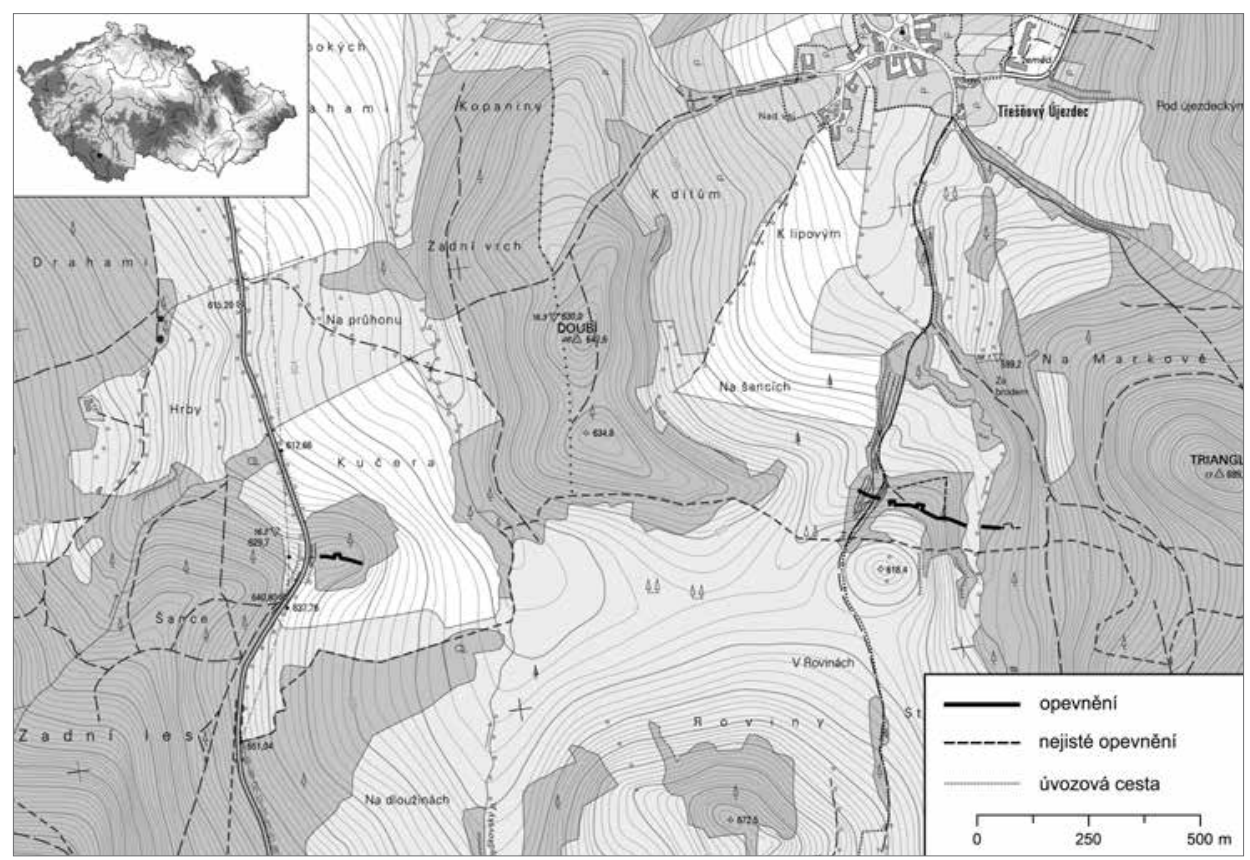

Obr. 1. Zaměření průběhu opevnění a úvozových cest na podkladu Základní mapy ČR 1 : 10000 (mapový list 32-21-08). Abb. 1. Vermessung des Verlaufs der Befestigung und der Hohlwege anhand der Grundkarte Tschechiens im Maßstab 1 : 10000 (Kartenblatt 32-21-08).

mocí totální stanice, využit byl průzkum detektorem kovů a v omezené míře také archeologická sondáž. Na terénní část navázala rešerše archivních pramenů.

\section{Popis lokalit}

Obce Vadkov a Třešňový Újezdec se nacházejí přibližně 23 kilometrů západně od Českých Budějovic. Z hlediska geomorfologie jsou položeny v 0,5 až 2 kilometry širokém údolí Lhenické brázdy, která je od západu lemována strmými svahy Žernovické vrchoviny a od východu Buglatskou vrchovinou (Demek et al. 2006, 266). Mezi oběma obcemi se zdvíhá ještě vrchol Doubí (643 m n. m.), jenž rozděluje již tak úzké údolí na dva menší koridory. Ze strategického hlediska se tedy jedná o velmi prríhodnou polohu, která nabízí dobrý rozhled severním směrem a umožňuje kontrolovat průchod Lhenickou brázdou.

\section{1 Úsek Vadkov}

Pozůstatky opevnění jižně od obce Vadkov na mírném zalesněném návrší Kučera byly objeveny v červenci 2013. Jedná se o jednoduchý valový násep, místy jen slabě znatelný, doplněný prríkopem o celkové délce 110 metrů (obr. 2:A). Terénní relikty jsou poměrně nevýrazné (obr. 3) a letecké laserové skenování je nezaznamenalo. Zhruba v polovině délky se linie opevnění zalamuje a vytváří tak přibližně pravoúhlý redan o rozměrech $8 \times 8$ metrů. ${ }^{2}$ Převýšení prríkopu a valu je nejvýraznější právě $v$ těchto místech, přičemž příkop dosahuje maximální hloubky 15 centimetrů a val maximální výšky 50 centimetrů. Př́́kop i redan jsou obráceny směrem k se- 

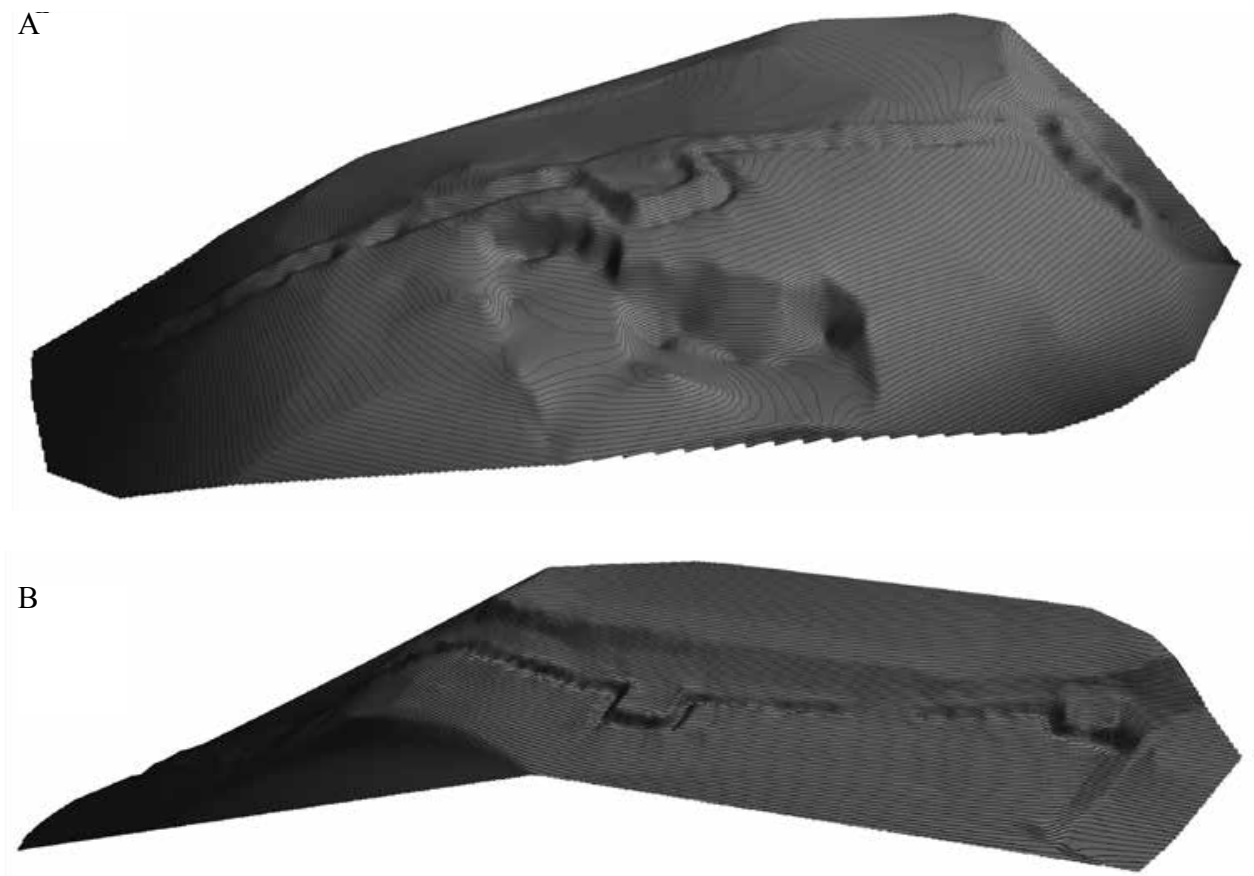

Obr. 2. Terénní model vadkovského (A) a újezdeckého (B) opevnění, pohledy od severu. Vizualizace J. John. Abb. 2. Geländemodell der Befestigung von Vadkov (A) und Újezdec (B), Ansicht aus Norden. Visualisierung J. John.

veru, odkud byl nejspíše očekáván případný útok. Severně od opevnění a zvláště ve východní části návrší je terén narušen lomy na kámen, jejichž chronologický vztah k opevnění je nejasný, nicméně nelze vyloučit, že těžba mohla některé terénní relikty zničit. Jak naznačují zachované zbytky úvozových cest, bylo opevnění př́ímo vázané na komunikaci, jež zde v podobě silnice č. 122 funguje dodnes.

\section{2 Úsek Třešňový Újezdec}

Opevnění na katastru Třešňového Újezdce bylo identifikováno až v červenci 2014, avšak již po prvotním ohledání byla patrná jasná souvislost s vadkovskými šancemi (obr. 2:B). Jedná se totiž o půdorysně shodný typ, pouze rozměrově větší. Linie příkopu a místy téměř neznatelného valu (obr. 4), z něhož vybíhají dva redany, je umístěna na jižním svahu mírného návrší (kóta $618 \mathrm{~m}$ n. m.) vzdáleného přibližně jeden kilometr jižně od kaple v obci Třešňový Újezdec. Val vede po vrstevnici mírného návrší, avšak zhruba po 100 metrech spadá dolů po př́krém úbočí směrem k Bezdrevskému potoku. Východní redan o rozměrech $8 \times 8$ metrů vykazuje větší odchylku na severoseverozápadě, západní s rozměry $8 \times 6$ metrů naopak odchylku k severoseverovýchodu. Stejně jako $\mathrm{v}$ prŕípadně vadkovského postavení je i toto opevnění přimknuté ke komunikaci, jež je $\mathrm{v}$ terénu doložena $\mathrm{v}$ podobě svazku minimálně devíti úvozových cest, které kopíruje dnešní polní cesta mezi Třešňovým Újezdcem a Smědečkem. Některé z těchto úvozů byly prot’aty krátkým př́íkopem, jenž respektuje hlavní linii opevnění, a proto mezi nimi můžeme předpokládat souvislost. Také na východní straně opevnění patrně nekončilo v nivě potoka - 

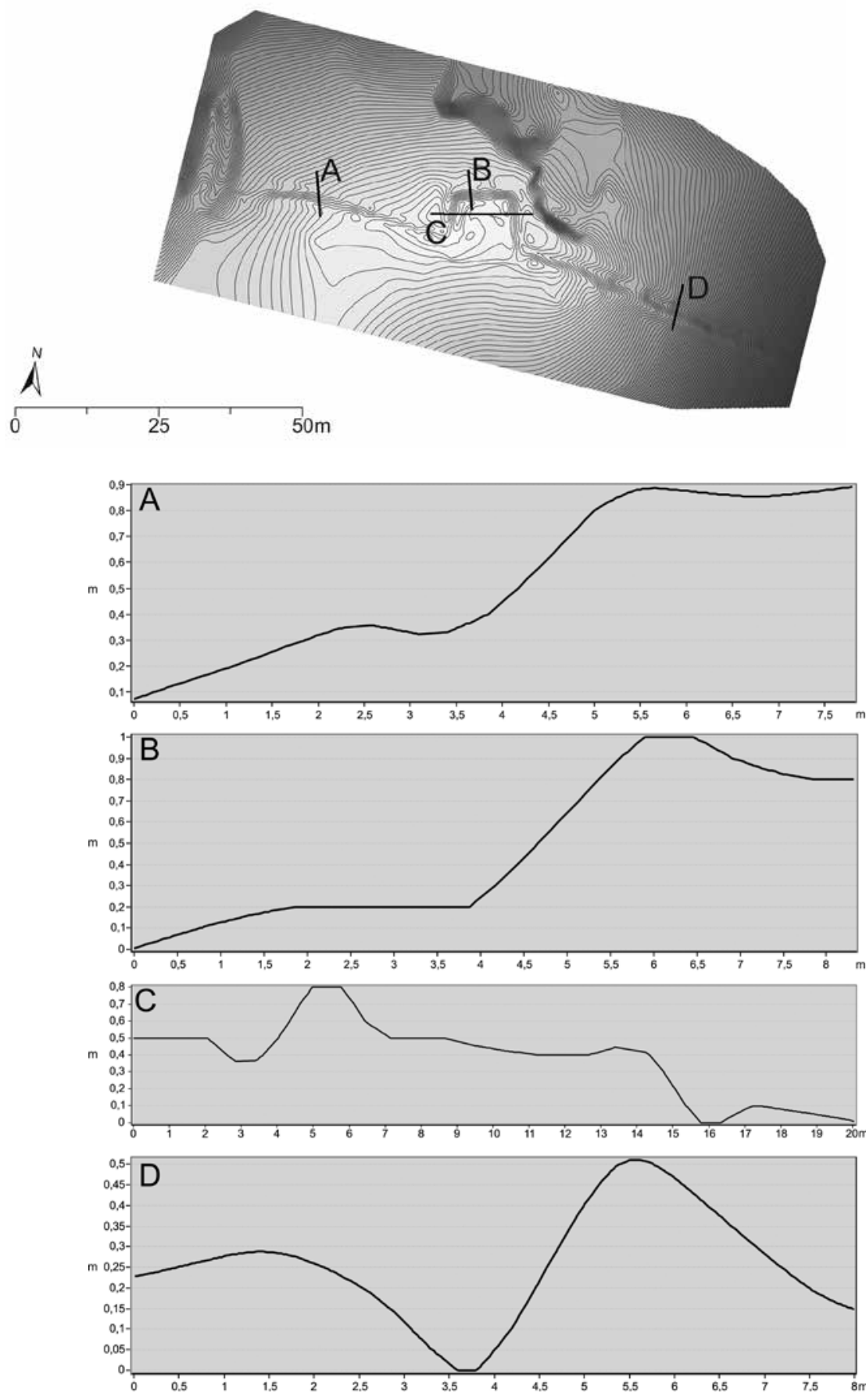

Obr. 3. Vadkov. Výškové profily terénních reliktů opevnění.

Abb. 3. Vadkov. Höhenprofile der Geländerelikte der Befestigung. 

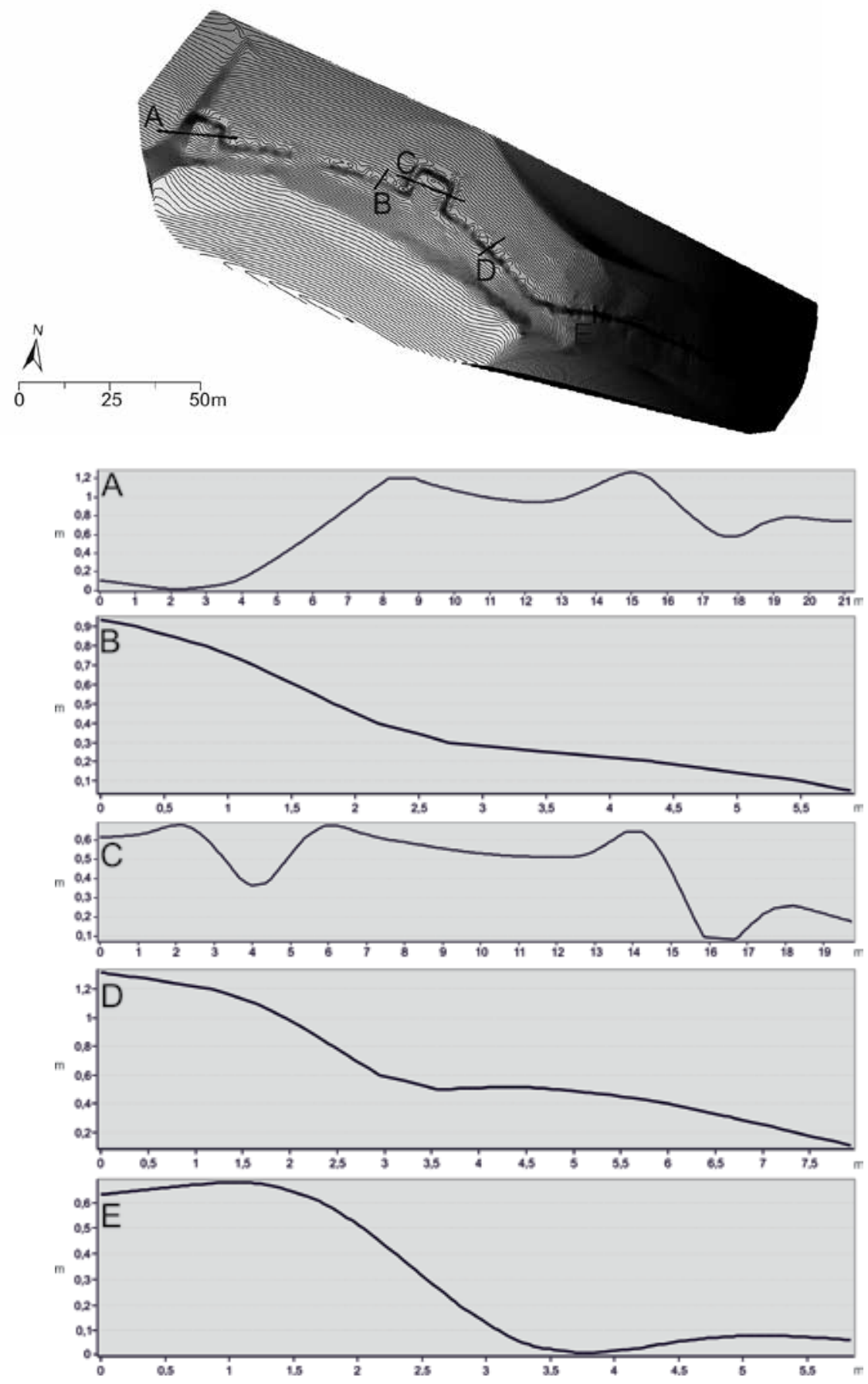

Obr. 4. Třešňový Újezdec. Výškové profily terénních reliktů opevnění.

Abb. 4. Třešňový Újezdec. Höhenprofile der Geländerelikte der Befestigung. 
nevýrazné terénní relikty př́ikopu a snad také třetího redanu ${ }^{3}$ byly zachyceny i na protějším svahu nad potokem. Celková délka linie opevnění včetně redanů a nejistých úseků činí 382 metrů.

Otevřená zůstává existence trojúhelníkovitého výběžku, jenž by tvořil předsunuté opevnění hlavní linie. Ten byl zachycen jen v podobě nízkého a místy nenápadného valu bez př́kopu, a tudíž nelze vyloučit, že je tento útvar pozůstatkem meze či hranice lesního pozemku, čemuž odpovídá i parcelace zachycená ve stabilním katastru, a se stavbou opevnění nemá spojitost. Stejně jako u Vadkova jsou relikty i na tomto úseku poměrně nezřetelné, a to i v př́ipadě nesporných částí, což se odrazilo i na leteckém laserovém skenování, které opevnění nezaznamenalo. Meze nalezeme i na rozhraní lesa a louky několik metrů za hlavní linií opevnění a nelze vyloučit, že byly též využity jako obranné prvky. Strategickou výhodu také mohly nabídnout srázy oddělující nivu Bezdrevského potoka a návrší kóty 618.

\section{Průzkum detektorem kovů}

Ve snaze získat datovací materiál byl v prostoru nově identifikovaných opevnění opakovaně proveden průzkum detektorem kovů. Byl získán soubor přibližně osmdesáti kovových předmětů, avšak valná většina z nich je subrecentního a recentního stáří. ${ }^{4}$ Drtivá většina předmětů byla nalezena na rozhraní hrabanky a světle hnědé lesní půdy, pouze v některých př́ípadech byly předměty vyzvednuty z větší hloubky, která však nepřesáhla 20 centimetrů.

Během zpracování souboru byly pro další analýzu vytř́iděny kovové předměty, které lze na základě tvaru a fabrikace datovat alespoň rámcově do středověku a novověku (tab. 1$){ }^{5}$

Nejpočetnější kategorií kovových nálezů z obou úseků opevnění jsou koňské podkovy (obr. $5: 3,5,9,10$; obr. $6: 3,4,6,7,8)$. Jedná se o typologicky a nejspíše i chronologicky nesourodý soubor, který vypovídá o využití koňské síly či o jezdectví ve zkoumaném prostoru. Nejčastěji jsou zastoupeny kované široké a ploché exempláře s ven vyhnutými ozuby, bez hmatce a s otvory pro podkováky na vnější straně ramen. Otvory jsou čtvercového průřezu, často jsou propojeny žlábkem. Soubor je možné na základě analogií (např. Krajíc 2003; Kubů-Zavřel 2009) datovat do vrcholného stř̌edověku a časného novověku.

Železný třemen (tab. 1:1; obr. 5:1), z něhož je zachováno jedno rameno s částí závěsu a plynule nasazeným zploštělým oválným stupadlem, nedovoluje $\mathrm{v}$ rámci vrcholného středověku a novověku bližší chronologické a typologické zařazení (pokud by se původně jednalo o symetrický třmen, bylo by možné uvažovat o typu IV dle Krajíc 2003, 114-118). Přestože byl třmen nalezen v blízkosti opevnění, nelze ho (stejně jako nálezy podkov ad.) s jistotou spojovat s výstavbou a využíváním opevnění. Čepel nože (tab. 1:23; obr. 6:2) získaná na úseku opevnění u Třešňového Újezdce nemusí nutně spadat do kategorie militarií a její chronologická souvislost s opevněním je též na úrovni hypotéz (srov. Waldhauser 2009, obr. 17).

Do kategorie zemědělského nářadí řadíme pouze jeden srp (tab. 1:17). Zemědělské nářadí nepatří $\mathrm{k}$ chronologicky citlivým předmětům - výše zmíněný nález můžeme typologicky řadit do skupiny srpů s obloukovitou čepelí (Krajíc 2003, 139-141).

Na každém z popisovaných úseků bylo získáno po jednom kovaném klínku (tab. 1:4, 14). Souvislost nálezu s využíáním opevnění je opět nejistá, jako pravděpodobnější se jeví ztráta při lesních pracích. Třemi nálezy (když nepočítáme podkováky, které jsou součástí nálezů podkov) jsou zastoupeny kované hřebíky. Není možné určit, zda se jedná o spojovací prvky konstrukcí či dokonce zbraní, nesnadná je též přesnější datace. Jedním exemplářem je dále zastoupen tzv. lavičník (tab. 1:24). Dalším chronologicky necitlivým předmětem je přezka (tab. 1:8, obr. 5:7). V tomto př́ípadě lze uvažovat o osobní výbavě či postrojích koně (srov. Waldhauser 2009, obr. 13). Kovaný pásek se dvěma proraženými otvory (tab. 1:7; obr. 5:4) není možno blíže určit.

\footnotetext{
3 Úseky opevnění v prostoru úvozových cest a za Bezdrevským potokem nebyly zahrnuty do terénního modelu (obr. 2:B).

4 Např́iklad kleště, pilník, hřebíky, drát, drobné mince; z militarií prázdné nábojnice 7,92 ×57 mm Mauser německé výroby, 7,62 × 25 a 7,62 × 39 mm Tokarev cvičné československé poválečné výroby, dále části vybuchlého německého granátu vz. 24/39.

5 Předkládaný článek není primárně zaměřen na morfologii a typologii středověkých a novověkých železných předmětů, při popisu i dataci vycházíme z dostupné literatury.
} 


\begin{tabular}{|c|c|c|c|}
\hline & č. & popis předmětu & obr. \\
\hline \multirow{5}{*}{ 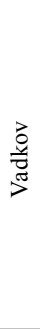 } & 1 & $\begin{array}{l}\text { deformovaný, téměř z poloviny zachovaný třmen původně hruškovitého tvaru } \\
\text { s plochým oválným stupadlem, rekonstruovaná délka cca } 140 \mathrm{~mm}\end{array}$ & $5: 1$ \\
\hline & 2 & $\begin{array}{l}\text { kovaná tyčinka kulatého průřezu (průměr } 10-11 \mathrm{~mm} \text { ) o délce } 175 \mathrm{~mm} \text { zakončená } \\
\text { očkem, ve kterém je uzavřeno další očko s hákem - součást vozu? }\end{array}$ & - \\
\hline & 3 & $\begin{array}{l}\text { kompletní podkova s masivními ven vyhnutými ozuby, na přední části vystupující } \\
\text { hmatec, šiŕka ramene 12-34 mm, šírka podkovy } 96 \mathrm{~mm} \text {, délka } 98 \mathrm{~mm}\end{array}$ & $5: 5$ \\
\hline & 4 & kovaný železný klínek, délka 54 mm, šířka 23 mm, max. síla 9 mm & - \\
\hline & 5 & $\begin{array}{l}\text { zlomek pravého ramene podkovy s ven vyhnutým obdélným ozubem, dochovaná } \\
\text { šírka ramene } 15-32 \mathrm{~mm} \text {, dochovaná délka } 81 \mathrm{~mm}\end{array}$ & $5: 3$ \\
\hline \multirow{22}{*}{ 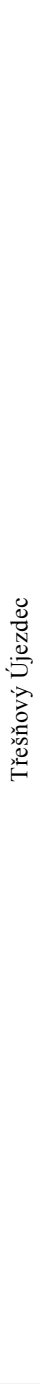 } & 6 & hřebík, tzv. podkovák, délka 46 mm & 5:6 \\
\hline & 7 & $\begin{array}{l}\text { kovaný železný pásek se třemi probitými kvadratickými otvory, délka } 148 \mathrm{~mm} \text {, } \\
\text { šírka } 26 \mathrm{~mm} \text {, síla } 5 \mathrm{~mm}\end{array}$ & $5: 4$ \\
\hline & 8 & $\begin{array}{l}\text { železná jednodílná obdélná přezka }(37 \times 29 \mathrm{~mm}) \text { s kulatým a oválným (původně } \\
\text { zřejmě hraněným) průřezem, trn nedochován - původně umístěn na delší straně }\end{array}$ & $5: 7$ \\
\hline & 9 & $\begin{array}{l}\text { mosazná pájená rolnička, průměr } 27 \mathrm{~mm} \text {, poškozena, uvnitř železná kulička } \\
\text { (průměr } 8 \mathrm{~mm} \text { ) }\end{array}$ & - \\
\hline & 10 & $\begin{array}{l}\text { téměř kompletní stěžejové nůžky s otevřenými oky, na čepelích kovářská značka } \\
\text { ve tvaru S, délka } 160 \mathrm{~mm}\end{array}$ & $6: 1$ \\
\hline & 11 & $\begin{array}{l}\text { podkova, část levého ramene nedochována, na pravém rameni nevýrazný ozub, šíř- } \\
\text { ka ramene } 14-29 \mathrm{~mm} \text {, šířka podkovy } 96 \mathrm{~mm} \text {, délka } 97 \mathrm{~mm}\end{array}$ & $6: 3$ \\
\hline & 12 & olověný kulatý projektil, mírně deformovaný, průměr $11 \mathrm{~mm}$, váha $5,9 \mathrm{~g}$ & - \\
\hline & 13 & hřebík s masivní hlavou čtvercového průřezu, dochovaná délka 44 mm & $5: 8$ \\
\hline & 14 & kovaný železný klínek, délka $45 \mathrm{~mm}$, šířka $19 \mathrm{~mm}$, max. síla $8 \mathrm{~mm}$ & - \\
\hline & 15 & $\begin{array}{l}\text { kompletní (rozlomena během nálezu) podkova s nízkými, téměř trojúhelníkovitými } \\
\text { ozuby, širrka ramene } 16-37 \mathrm{~mm} \text {, šiřka podkovy } 115 \mathrm{~mm} \text {, délka } 120 \mathrm{~mm}\end{array}$ & $5: 9$ \\
\hline & 16 & $\begin{array}{l}\text { pravé rameno podkovy s drobným ven vyhnutým obdélným ozubem, šiřka ramene } \\
15-32 \mathrm{~mm} \text {, dochovaná délka } 105 \mathrm{~mm}\end{array}$ & $5: 10$ \\
\hline & 17 & poškozený srp, s obloukovitou nízkou čepelí, celková délka přibližně $470 \mathrm{~mm}$ & - \\
\hline & 18 & $\begin{array}{l}\text { hřeb s plochou hlavou (průměr } 31 \mathrm{~mm} \text {, nedochována kompletně), síla dříku max. } \\
9 \mathrm{~mm}\end{array}$ & - \\
\hline & 19 & $\begin{array}{l}\text { levé rameno podkovy s masivním téměř trojúhelníkovitým ozubem, šířka ramene } \\
16-34 \mathrm{~mm} \text {, dochovaná délka } 108 \mathrm{~mm}\end{array}$ & $6: 4$ \\
\hline & 20 & $\begin{array}{l}\text { kompletní podkova se čtvercovými ozuby, šíŕka ramene } 16-30 \mathrm{~mm} \text {, šíŕka podkovy } \\
103 \mathrm{~mm} \text {, délka } 105 \mathrm{~mm}\end{array}$ & $6: 6$ \\
\hline & 21 & hřebík, tzv. podkovák, hraněný, délka 38 mm, síla max. 5 mm & - \\
\hline & 22 & $\begin{array}{l}\text { kovaný železný pásek, délka } 98 \mathrm{~mm} \text {, šířka } 22 \mathrm{~mm} \text {, síla max. } 6 \mathrm{~mm} \text {; zhruba ve tře- } \\
\text { tině délky proražen kvadratický otvor o straně } 5 \mathrm{~mm}\end{array}$ & - \\
\hline & 23 & $\begin{array}{l}\text { čepel nože, délka } 154 \mathrm{~mm} \text {, šíŕka max. } 33 \mathrm{~mm} \text {, síla čepele max. } 3 \mathrm{~mm} \text {, střenka či } \\
\text { řap odlomen }\end{array}$ & $6: 2$ \\
\hline & 24 & lavičník, délka $102 \mathrm{~mm}$, síla 2-10 mm & - \\
\hline & 25 & šídlo čtvercového průřezu, síla max. $5 \mathrm{~mm}$, délka $54 \mathrm{~mm}$ & $6: 5$ \\
\hline & 26 & $\begin{array}{l}\text { levé rameno podkovy s obdélníkovitým ozubem, šířka ramene } 16-26 \mathrm{~mm} \text {, docho- } \\
\text { vaná délka } 106 \mathrm{~mm}\end{array}$ & $6: 7$ \\
\hline & 27 & $\begin{array}{l}\text { kompletní podkova s nízkými čtvercovými ozuby, šířka ramene } 20-31 \mathrm{~mm} \text {, šířka } \\
\text { podkovy } 110 \mathrm{~mm} \text {, délka } 105 \mathrm{~mm}\end{array}$ & $6: 8$ \\
\hline
\end{tabular}

Tab. 1. Soupis vybraných kovových předmětů nalezených v prostoru opevnění.

Tab. 1. Verzeichnis ausgewählter, im Bereich der Befestigung entdeckter Metallgegenstände. 

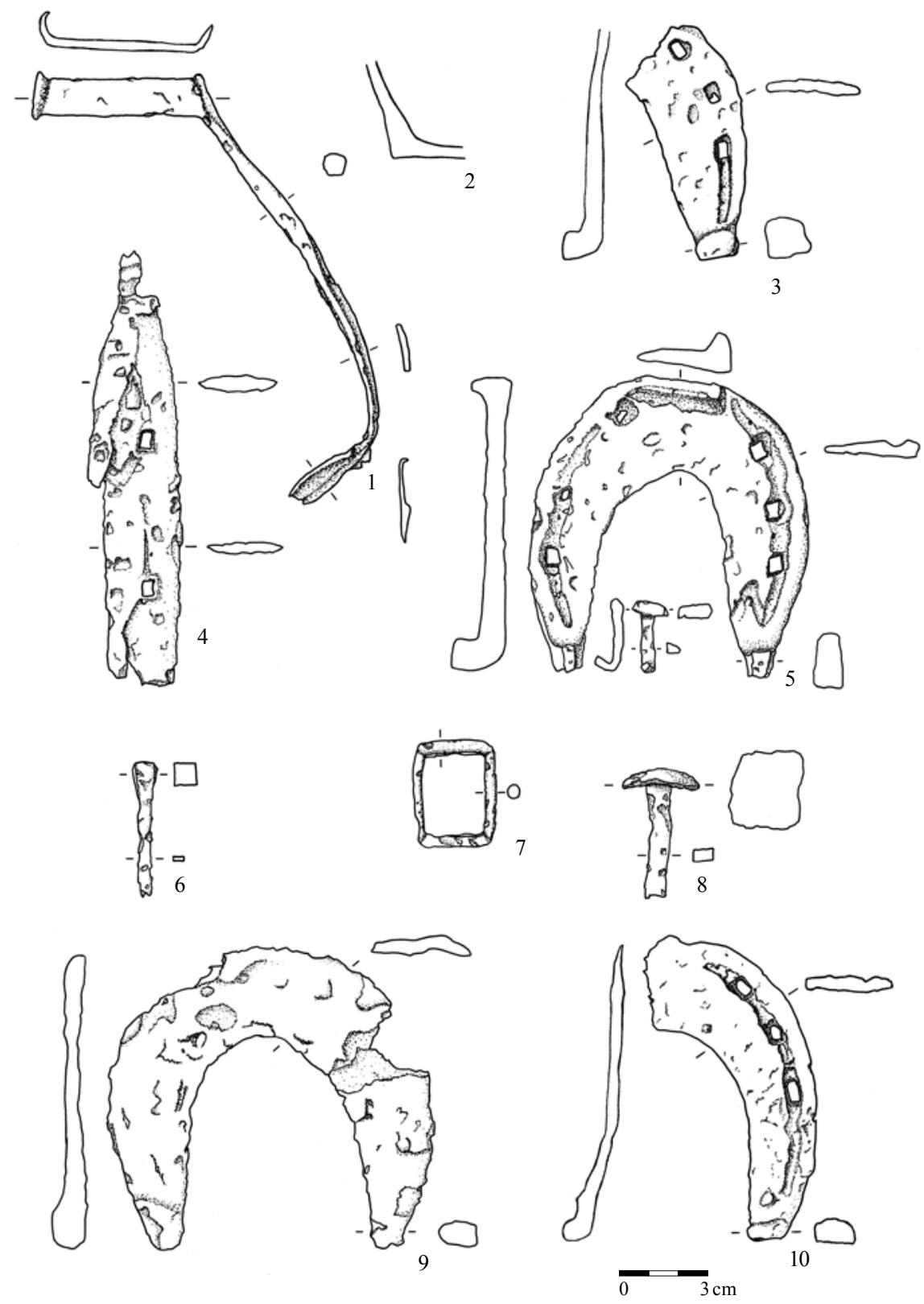

Obr. 5. Kovové předměty nalezené během průzkumu detektorem kovů a keramika z výzkumu vadkovského redanu. Kresba J. Kocina.

Abb. 5. Während der Metalldetektorensuche gefundene Metallgegenstände und Keramik von der Grabung am Redan von Vadkov. Zeichnung J. Kocina. 

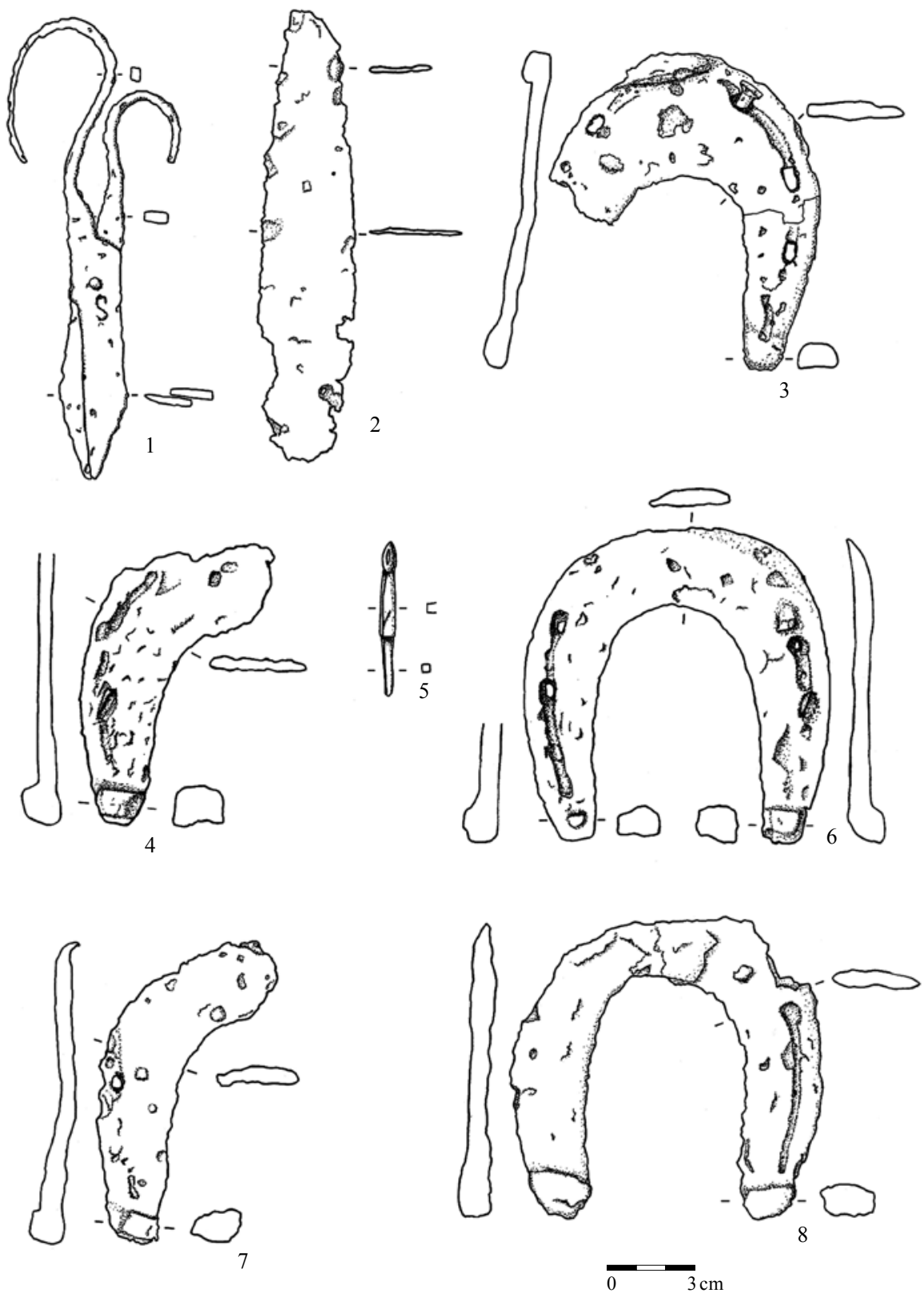

Obr. 6. Kovové předměty nalezené během průzkumu detektorem kovů. Kresba J. Kocina.

Abb. 6. Während der Metalldetektorensuche gefundene Metallgegenstände. Zeichnung J. Kocina. 
Za specializované nástroje či osobní výbavu můžeme považovat nalezené tzv. krejčovské či stěžejové nůžky (tab. 1:10; obr. 6:1; analogie např. Krajíc 2003, 158-159). V kontextech polních táborů a opevnění s dlouhodobějším pobytem vojsk nejsou nůžky neobvyklým nálezem (srov. Waldhauser 2009, obr. 19, č. 2, 3, 6). Drobným dokladem řemesla je též kované šídlo (tab. 1:25; obr. 5:5; Krajíc 2003, 152-153; Richter 1982, 157-158). Jedním kusem je zastoupena rolnička (tab. 1:9), podle způsobu výroby (pájení) uvažujeme při dataci spíše o mladším úseku novověku (k rolničkám např. Fröhlich-Chvojka-Michálek 2010). Průzkum přinesl jeden nález litého, mírně deformovaného, olověného projektilu (tab. 1:12). Jeho ráže a váha jsou menší než u běžných projektilů ručních palných zbraní z období třicetileté války, ale nelze vyloučit jeho využití do nějakého typu pistole (Hrnčiř́ík 2011; Török 2011; Šámal 2011, 54-55). Je nutné si uvědomit, že jednotlivé projektily jsou v novověku v českém prostředí běžným, téměř všudypř́ítomným nálezem souvisejícím např́íklad s lovem.

\section{Sondáž}

Na přelomu dubna a května 2014 byla v prostoru vadkovského redanu položena zjištovací sonda o rozměrech $1 \times 6$ metrů, která protala val i prríkop. $Z$ nálezové situace je patrné (obr. 8), že základ valu tvořila linie větších kamenů usazených poměrně nahodile a bez lícování. Na tento základ byl následně navršen hliněný násep bez složitější úpravy. Příkop se na profilu jevil jako poměrně mělký bez výrazněji zašpičatěného dna. Již při skrývání svrchních vrstev se na koruně valu objevily kruhové koncentrace uhlíků, které by snad mohly být pozůstatkem lehkého dřevěného opevnění, ovšem nelze také vyloučit, že se jednalo o spálené kořeny nebo větve okolních stromů. Kvůli možné kontaminaci nebyly tyto uhlíky použity pro radiokarbonové datování. Vzorky byly odebrány až z mechanické úrovně 2, která se již dostala pod těleso valu a kde bylo opět možné pozorovat několik koncentrací uhlíků. Výsledné datum spadá při $95,4 \%$ pravděpodobnosti do intervalu $1488-1604$ ADcal. ${ }^{6}$ Zde je ovšem nutné vzít v úvahu tzv. old wood effect (Schiffer 1986). Pokud uhlík pocházel z jádrového dřeva vzrostlého stromu, zvláště z některé $z$ dlouhověkých dřevin, např́iklad dubu, bude výsledné datum zřejmě výrazně starší než událost, při níž došlo ke spálení dřeva. Na této mechanické úrovni byly v prostoru př́íkopu a v tělese valu odkryty také dva malé fragmenty keramiky:

1) zlomek dna a př́dní hrncovité (?) nádoby o rozměrech $36 \times 27 \mathrm{~mm}$, síla stěny $4 \mathrm{~mm}$, síla dna 4-5 mm, barva vně černá a oranžovohnědá, uvnitř černá, datace: přelom 13. a 14. století, spíše první polovina 14. století (obr. 5:2),

2) zlomek stěny nádoby, rozměry $40 \times 28 \mathrm{~mm}$, síla $4 \mathrm{~mm}$, materiál s prŕměsí jemného ostřiva, dobře vypálen, barva šedá, datace: 14.-15. století.

Oba drobné zlomky středověké keramiky nalezené v tělese valu nedovolují přesnější dataci vzniku opevnění, pouze ji posouvají do středověku a novověku. Lze předpokládat, že během stavby opevnění byly v dotčeném prostoru již archeologizovány a s přemist'ovanou zeminou byly $\mathrm{v}$ tělese valu druhotně uloženy.

\section{Interpretace a výpověd’ písemných pramenů}

Prvním východiskem pro interpretaci je současný vznik obou úseků opevnění. Dokládají to nejen výše popsané shodné znaky konstrukce, ale i umístění opevnění v terénu. V jedné pomyslné linii přetínají průchod Lhenickou brázdou. Přestože jsou umístěny na poměrně nízkých návrších, nabízejí velmi dobrý rozhled severním směrem a možnost kontrolovat tento prostor minimálně až k městečku Lhenice (obr. 9). Patrná je také snaha kontrolovat tehdejší komunikace, 

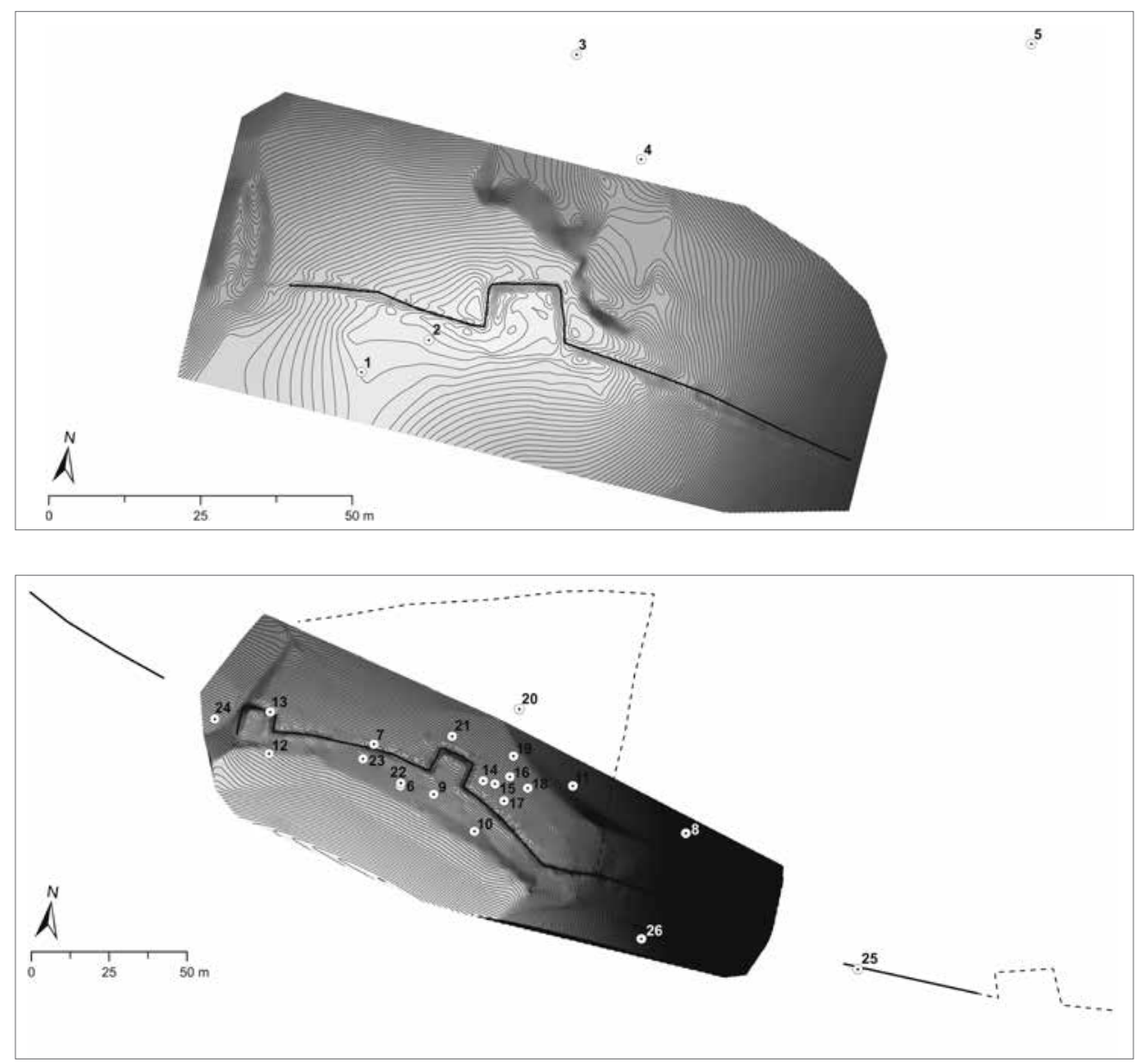

Obr. 7. Umístění nalezených kovových předmětů ve vztahu k průběhu opevnění, označení nálezů odpovídá číslování $v$ tabulce.

Abb. 7. Lage der gefundenen Metallgegenstände in Bezug zum Verlauf der Befestigung, die Kennzeichnung der Funde entspricht der Nummerierung der Tabelle.

která může být doložena prostorovým vztahem obou opevněných poloh k reliktům úvozových cest. Ty $\mathrm{k}$ linii valu přiléhají $\mathrm{v}$ obou prŕípadech zleva a téměř $\mathrm{v}$ bezprostřední blízkosti.

Důležitým vodítkem pro dataci byl pomístní název „Na Schanze“ zaznamenaný na císařském povinném otisku stabilního katastru Třešňového Újezdce z roku 1837. Lze se tedy oprávněně domnívat, že opevnění souvisí s konflikty předcházejícími tomuto datu. V prostoru jižních Čech můžeme uvažovat například o vpádu pasovských vojsk (1611) či válce o rakouské dědictví (1740-1748), avšak nejvíce se tohoto kraje dotkla třicetiletá válka, zvláště její první fáze, tzv. česká válka (1618-1620). Úvahy o době vzniku opevnění byly proto směřovány právě k tomuto období.

V počátečních letech třicetileté války se v jižních Čechách nacházela vojska obou znepřátelených stran - stavovská i císařská (Volf 1960,18). Jejich působení lze časově vymezit zhruba obdobím od bitvy u Lomnice nad Lužnicí 9. listopadu 1618 po bitvu na Bílé hoře 8 . listopadu 1620, ale i po této porážce stavů zůstala na jihu Čech drobná místa odporu (Zvíkov, Třeboň, s nimiž se císařští definitivně vypořádali až v roce 1622 - Polišenský 1960, 88-119; Thille-Čenský $1875,203)$. 


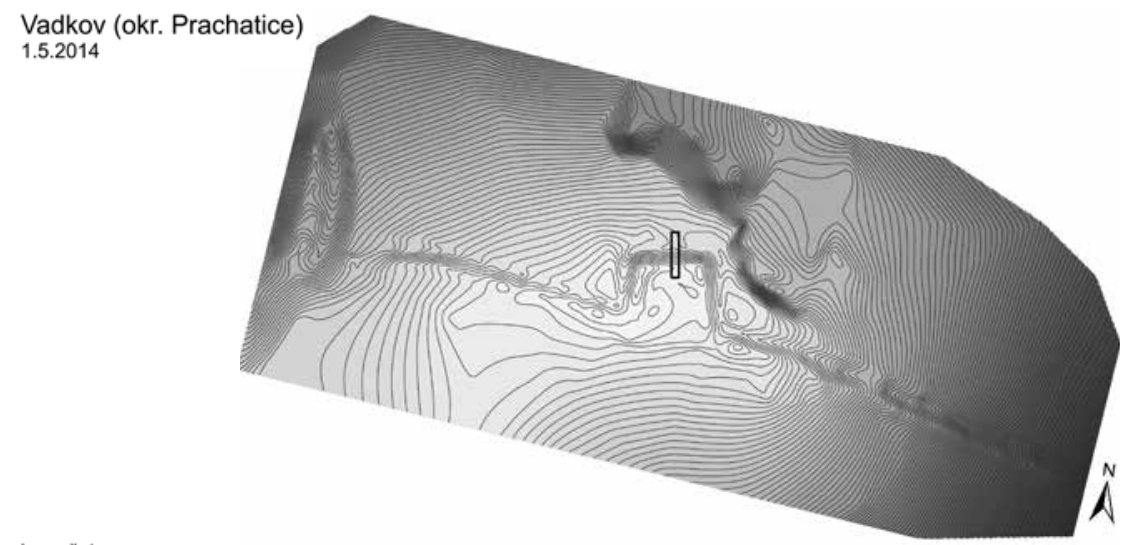

úroveň 1
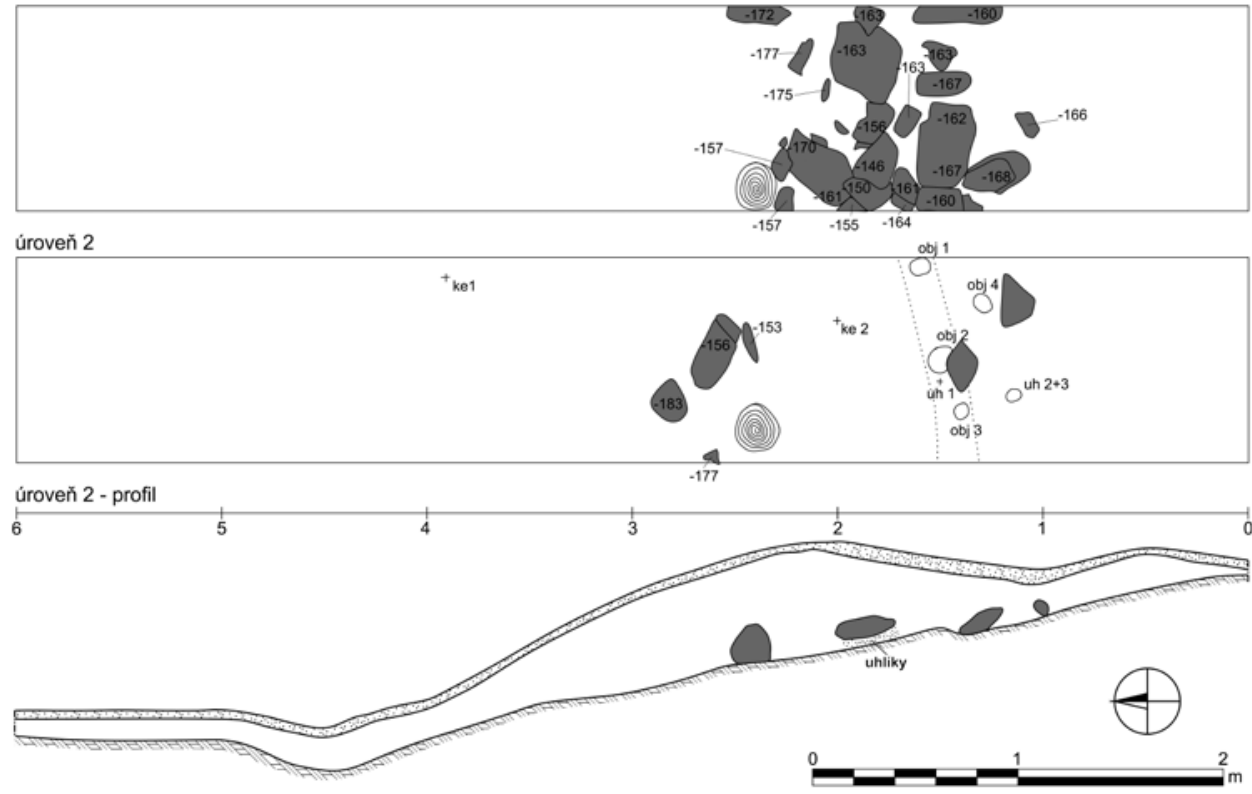

Obr. 8. Půdorys a profil sondy protínající val a př́íkop vadkovského redanu. Kresba J. Bumerl.

Abb. 8. Grundriss und Profil des durch Wall und Graben gehenden Sondierschnitts des Redan in Vadkov. Zeichnung J. Bumerl.

Na podzim roku 1618 však situace na jihu Čech byla př́iznivá spíše pro stavovské (Volf 1960, 89-92). Po bitvě u Lomnice nad Lužnicí se poražení císařští neplánovaně stáhli do Českých Budějovic, kde byli nuceni zůstat přes zimu (Volf 1960, 90). Díky nedokonalému obklíčení města stavovskými se jim však podařilo prorazit směrem na jih a brzy ovládali cestu na Český Krumlov a šumavský prostor mezi Želnavou a Vyšším Brodem (Volf 1961, 28). Území západně od trasy Český Krumlov - České Budějovice kontrolovali povětšinou stavovští, ale už 7. prosince 1618 požádala městská rada Lhenic císařské o možnost vstoupit do poddanství pod Český 


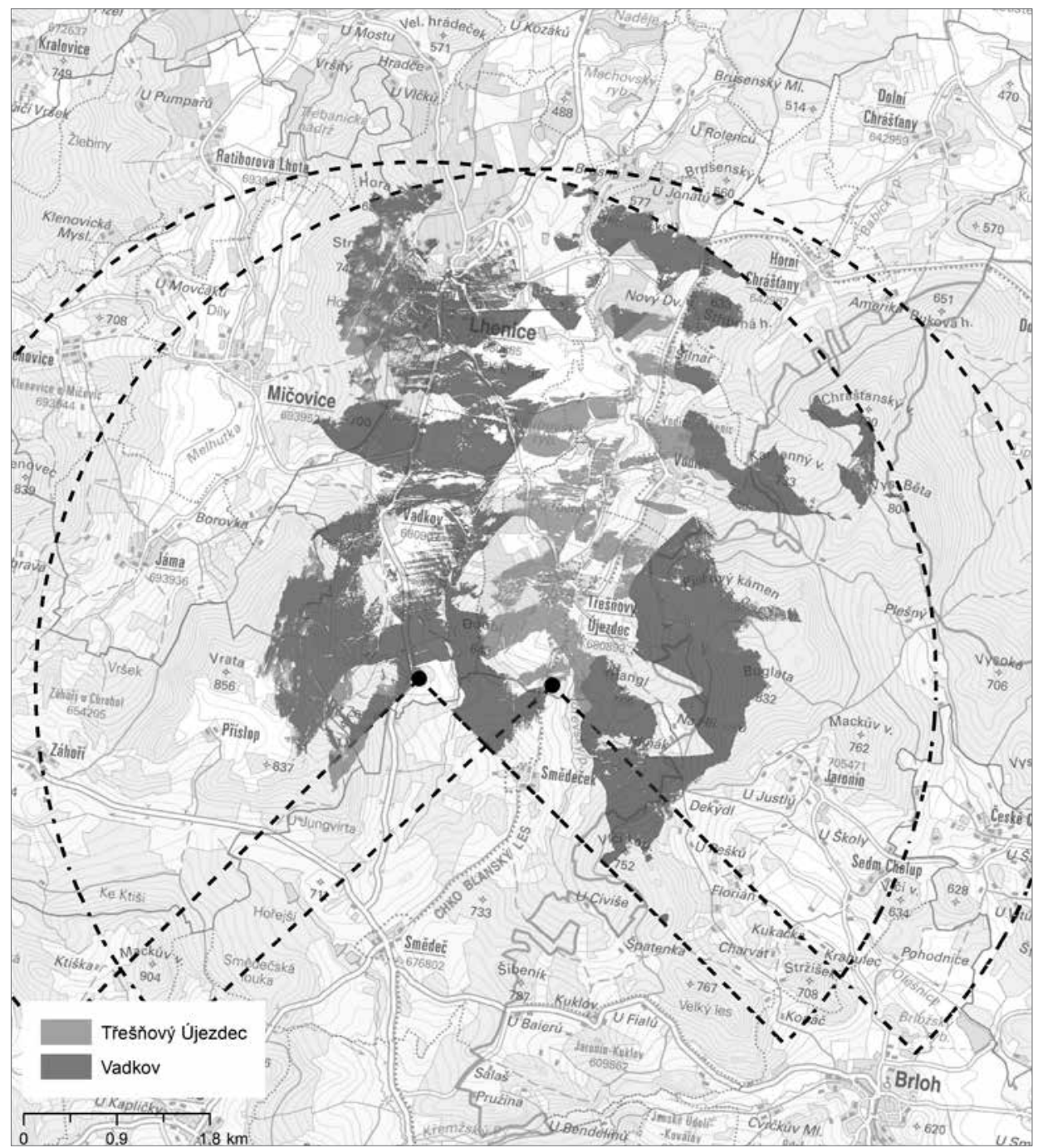

Obr. 9. Analýza viditelnosti z vadkovského a újezdeckého opevnění do vzdálenosti do 5 kilometrů, šířka výseče $270^{\circ}$, výška stanoviště 1,7 metru. Vizualizace V. Vondrovský.

Abb. 9. Analyse der Sichtbarkeit der Befestigung von Vadkov und Újezdec in einer Entferung von bis zu 5 Kilometern, Breite des Ausschnitts $27^{\circ}$, Höhe des Standortes 1,7 Meter. Visualisierung V. Vondrovský.

Krumlov, jak tomu bylo dříve, než se Lheničtí stali poddanými Martina Breynera z Veveří a Mysletína, jenž byl v době odeslání této žádosti již mrtev.?

Lhenice byly neopevněné a umístěné v otevřené krajině Lhenické brázdy, pouze od západu chráněné vrchem Stráže (742 m n.m.). Za tohoto stavu bylo samotné městečko jen těžko hájitelné, avšak jeho umístění v jinak stavovským vojskem ovládaném území bylo pro císařské dozajista výhodné. Jedním z hlavních úkolů lhenické posádky se tak zřejmě stala kontrola

7 SOA Třebon̆, Rodinný archiv (dále RA) Buquoyů, II/T 36, inv. č. 730, kart. 100, 409/2. Plná moc města Lhenice jeho zástupcům při jednání s H. Des Foursem o vstupu do poddanství pod Český Krumlov; tamtéž, 409/3. Prosba lhenické městské rady o přijetí města do poddanství pod Český Krumlov. 
stavovských v Netolicích, nacházejících se 7 kilometrů severně (Volf 1961, 102-108). O pohybech vojsk kolem Netolic se také zachovalo několik zpráv. ${ }^{8}$ Je možné, že oba úseky opevnění vznikly již v době po př́íklonu Lhenic na císařskou stranu. Důvodem mohla být př́ípadná ochrana ústupové cesty ze Lhenic směrem na jih. K události, jež se z hlediska vzniku opevnění u Vadkova a Třešňového Újezdce zdá nejpravděpodobnější, došlo v noci z 29. na 30. března 1619. Té noci se objevilo stavovské vojsko o síle 200 jezdců a 300 pěších mezi Lhenicemi a Vadkovem. Císařský kapitán Antonio Brucio o tom neprodleně informoval generála Buquoye a žádal o urychlené vyslání posil. ${ }^{9}$ Je možné, že obrannou pozici vybudovalo císařské vojsko ve velkém spěchu právě kvůli tomuto incidentu, o čemž by svědčily i poměrně úsporné rozměry obou úseků opevnění. O tom, jak celá vypjatá situace dopadla, již prameny mlčí. Lze předpokládat, že se stavovští stáhli zpět a $\mathrm{k}$ boji nedošlo. Tuto variantu také podporuje poměrně málo početný soubor kovových artefaktů, zvláště militarií, na nalezišti v porovnání s jinými zkoumanými opevněními, na kterých k ozbrojeným střetům prokazatelně došlo (Beneš et al. 1995; Waldhauser 2009; Šámal 2011). Vesnice Vadkov dále v písemných pramenech již zmiňována není, zatímco o Lhenicích se píše v polovině května 1619 pouze v souvislosti s jejich skvělými sádky, v nichž byly chovány velké štiky a kapři. ${ }^{10}$

Je poměrně nepravděpodobné, že by opevnění mohlo vzniknout později v období po bitvě u Záblatí 10. června 1619, kdy vítězní císařští velmi rychle obsadili i další oblasti jižních Čech. Konkurenční Netolice byly zničeny císařským útokem krátce před samotnou bitvou u Záblatí a opevněné polohy jižně od Lhenic tak ztratily strategický význam (Volf 1962, 123-134).

Samozřejmě je také možné, že opevnění bylo využito i druhotně v následných konfliktech. V tomto ohledu je důležité, že svým umístěním přesně kopíruje hranice Prácheňského a Bechyňského kraje, jež byly zrušeny reformou krajského uspořádání v letech 1849-1850. Tato hranice zcela nezanikla a byla mimo jiné využita při odstoupení pohraničí v roce 1938. Zatímco katastry Vadkova a Třešňového Újezdce zůstaly nadále součástí českého území, obce dále na jih, kde převažovalo německé obyvatelstvo, již připadly třetí říši. Během neklidného mnichovského období v říjnu 1938 však zaujala německá armáda postavení i na severním úbočí vrchu Vrata (856 m n. m.) u Vadkova, ${ }^{11}$ a nelze vyloučit, že byla využita také starší opevnění, či alespoň jejich strategické polohy. Dále můžeme uvažovat o využití prostoru jako cvičiště lidových milic po roce 1948 (O. Petrášek, ústní sdělení), což dokládá řada subrecentních militarií. Podoba nově identifikovaných opevnění se ale zcela liší od okopů běžně budovaných v průběhu 20. století.

\section{Závěr}

Relikty dosud neznámých opevnění u Vadkova a Třešňového Újezdce byly identifikovány na základě toponym a následného průzkumu přímo v terénu. Tato metoda má $\mathrm{i} v$ době nástupu leteckého laserového skenování stále své nezastupitelné místo, nebot' př́íkopy ani valy se v naskenovaných datech vůbec neprojevily, což může být způsobeno jejich malým převýšením vůči okolnímu terénu, který je navíc pokryt lesní vegetací.

Relikty se s přispěním mapových podkladů a archeologických i písemných pramenů podařilo $\mathrm{s}$ největší pravděpodobností interpretovat jako postavení části císařské armády z konce března roku 1619. Za skutečně průkazný můžeme považovat vznik před rokem 1837, jenž je doložen otiskem stabilního katastru. Archeologické prameny, jako jsou nalezené fragmenty keramiky a radiokarbonové datování, dovolily pouze velmi hrubé vymezení, které se nicméně shoduje s výslednou interpretací. Stejně tak průzkum detektorem kovů nepřinesl jednoznačně datovatelné předměty, které by bylo možné spojit s dobou funkce opevnění. Zásadní informace

8 SOA Třeboň, RA Buquoyů, II/T 36, inv. č. 730, kart. 103, 398. Collalto 11. 5. píše, že se neprátelé pohybují mezi Netolicemi, Prachaticemi a Vodňany; tamtéž, 718/2. Huerta 16. 5. píše, že nepřátelé jsou kolem Netolic a Vimperka.

9 SOA Třebon̆, RA Buquoyů, II/T 36, inv. č. 730, kart. 102, 67/I/670.

10 SOA Třeboň, RA Buquoyů, II/T 36, inv. č. 730, kart. 103, 208g.

11 Wehrmacht později dne 17. 10. své pozice opustil a stáhl se na sudetoněmecké území. V listopadu opustila Vadkov i německá finanční stráž a území se vrátilo pod kontrolu Česko-Slovenské republiky. SOkA Prachatice, Archiv obce Vadkov, inv. č. 2, Pamětní kniha obce Vadkova III, 1937-1962, s. 76-77. 
přineslo až studium korespondence císařských velitelů z počátku třicetileté války, v níž ovšem doslovné zmínky o tomto postavení chybí. V úvahu je třeba brát i pozdější druhotné využívání těchto strategických poloh.

Otázkou zůstává, zda opevnění byla během válečného stř̌etnutí skutečně využita. Téměř úplná absence dobových militarií, zvláště projektilů, v souboru získaném při průzkumu detektorem kovů napovídá, že nikoliv. Vzhledem k přítomnosti starších vkopů je patrné, že obě lokality již byly v minulosti navštíveny amatérskými hledači, a tudíž i přes intenzivní průzkum badatelského týmu není soubor kovových artefaktů úplný. Stejně tak mohou být v budoucnu identifikovány ještě další úseky opevnění a bude vhodné pokračovat v průzkumu detektorem kovů. Přesto se domníváme, že i za současného stavu výzkumu přinesla opevnění u Vadkova a Třešňového Újezdce nové informace k průběhu válečných události třicetileté války na jihu Čech.

Autoři článku děkují za pomoc během výzkumu vadkovského redanu Haně Hojerové, Danielu Kovářovi, Jiřímu Bumerlovi a Michaele Divišové. Za cenné informace týkající se situace v okolí Vadkova v roce 1938 děkujeme Jindřichu Vágnerovi a za pomoc s překladem italsko-španělských pramenů Ondřeji Stoličkovi.

Vznik tohoto článku byl podpořen Grantovou agenturou Jihočeské univerzity, projekt č. 145/2016 H - Rozvoj doktorských studijních programů na FF JU - teoretické, metodické a ediční aspekty programů Historické vědy a Archeologie.

\section{Prameny}

Státní oblastní archiv Třeboň, Rodinný archiv Buquoyů, II/T 36, inv. č. 730, kart. 100, 409/2, kart. 100, 409/3, kart. 103, 398, kart. 103, 718/2, kart. 102, 67/I/670, kart. 103, 208g.

Státní okresní archiv Prachatice, Archiv obce Vadkov, inv. č. 2, Pamětní kniha obce Vadkova III, 1937-1962.

\section{Literatura}

BENEŠ, J.-KUBU゚, F.-TÖRÖK, J., 1995: Soubor militárií z počátku třicetileté války z Volarských šancí Die an den Wallerer Schanzen gefundene Militarienkollektion aus dem Anfang des Dreißigjährigen Krieges, AR XLVII, 461-480.

DEMEK, J.-MACKOVČIN, P., edd., 2006: Hory a nížiny: Zeměpisný lexikon ČR. Brno.

FRÖHLICH, J., 1986: Opevnění u Soumarského mostu, Výběr 23, 294-295.

- 1990: Opevnění u Strážného na Šumavě, Výběr 27, 223-226.

- 2000: Historická opevnění jižní zemské hranice, Výběr 37, 285-290.

FRÖHLICH, J.-CHVOJKA, O.-MICHÁLEK, J., 2010: Nálezy rolniček v jižních Čechách, AVJČ 23, 205-220.

HRNČIŘÍK, P., 2011: Příspěvek k nálezům munice do ručních palných zbraní v prostoru bojiště Rozvadov 1621, Sborník muzea Českého lesa v Tachově 32, 17-21.

KRAJÍC, R., 2003: Sezimovo Ústí - archeologie středověkého poddanského města. 3. Kovárna v Sezimově Ústí a analýza výrobků ze železa 1 . Praha.

KUBUீ, F.-ZAVŘEL, P., 1988: Pozůstatky valového opevnění rakouské armády v bitvě u Zahájí dne 25. 5. 1742, AVJČ 5, 183-190.

- 2009: Zlatá stezka. Historický a archeologický výzkum významné středověké obchodní cesty. 3. Úsek Kašperské Hory - státní hranice. České Budějovice.

POLIŠENSKÝ, J., 1960: Třicetiletá válka a český národ. Praha.

RICHTER, M. 1982: Hradišt'ko u Davle. Městečko ostrovského kláštera. Praha.

REIMER, P. J. et al., 2013: Reimer, P. J.-Bard, E.-Bayliss, A.-Beck, J. W.-Blackwell, P. G.-Bronk Ramsey, C.-Buck, C. E.-Cheng, H.-Edwards, R. L.-Friedrich, M.-Grootes, P. M.-Guilderson, T. P.Haflidason, H.-Hajdas, I.-Hatté, C.-Heaton, T. J.-Hoffmann, D. L.-Hogg, A. G.-Hughen, K. A.Kaiser, K. F.-Kromer, B.-Manning, S. W.-Niu, M.-Reimer, R. W.-Richards, D. A.-Scott, E. M.Southon, J. R.-Staff, R. A.-Turney, C. S. M.-Van Der Plicht, J., INTCAL13 and marine INTCAL13 radiocarbon age calibration curves $0-50,000$ years cal BP, Radiocarbon 55, 1869-1887. 
SCHIFFER, M. B., 1986: Radiocarbon dating and the "old wood" problem: the case of the Hohokam chronology, Journal of Archaeological Science 13, 13-30. DOI: https://doi.org/10.1016/0305-4403(86)90024-5

ŠÁMAL, Z., 2011: Archeologové na bojišti. Několik poznámek k detektorovému průzkumu rakovnického bojiště z roku 1620. In: Bitva u Rakovníka 1620, 50-59. Rakovník.

THILLE, J.-ČENSKÝ, F., 1875: Česká válka od roku 1618 do roku 1622. Historicko-vojenská studie. Praha.

TÖRÖK, J., 2011: Posouzení a průzkum militárií a ostatních kovových nálezů z bojiště roku 1621 u Rozvadova v rámci konzervace, Sborník muzea Českého lesa v Tachově 32, 21-23.

VOLF, M., 1960: Jihočeské bojiště v prvních měsících českého povstání roku 1618, JSH 29, 18-22, 82-92.

- 1961: Válka v jižních Čechách v zimě a na jaře 1618-1619, JSH 30, 102-114.

- 1962: Bitva u Velkého Záblatí a její následky, JSH 31, 123-134.

VONDROVSKÝ, V. a kol., 2015: Vondrovský, V.-Pták, M.-Kovář, D.-John, J.-Hojerová, H., Zpráva o výsledcích terénní prospekce v rámci projektu Linecká stezka, AVJČ 28, 81-99.

WALDHAUSER, J., 2009: Švédský vojenský tábor ze třicetileté války na katastrech Staré Boleslavi (okr. Praha-východ) a Hlavence (okr. Mladá Boleslav), ASČ 13, 939-964.

\section{Zusammenfassung}

\section{Eine neu identifizierte Feldbefestigung in der Region Lhenice (Bezirk Prachatice)}

Der vorliegende Beitrag stellt die Ergebnisse der Untersuchung von neu identifizierten Feldbefestigungen im Kataster der Gemeinden Vadkov und Třešňový Újezdec in der Region Lhenice (Bezirk Prachatice) vor. Zu der Entdeckung ist es Dank den Toponymen „Schanze“ und „Auf den Schanzen“ gekommen, die zur Geländeuntersuchung den Anhaltspunkt lieferten. Durch ein Airborne Laserscanning konnten jedoch keine undeutlichen Relikte im waldbedeckten Gelände sichtbar gemacht werden. Beide identifizierten Abschnitte haben die Form einer Linienbefestigung mit annähernd rechtwinkligen, redanartigen Abmessungen. Die Befestigungen nehmen strategische Lagen auf leichten Anhöhen ein, die eine gute Aussicht nach Norden hin bieten, von wo aus ein Vorrücken des Feindes erwartet wurde. Erkennbar ist auch ihre Anbindung an die Verkehrswege, die durch verschwundene Hohlwege belegt ist, die ziemlich nah an die Walllinie und den Graben anschließen. Im Rahmen einer zerstörungsfreien Untersuchung der Fundstelle wurden die Geländerelikte mit einer Totalstation vermessen und mit einem $\mathrm{Me}-$ talldetektor abgesucht. Obwohl der Komplex der gefundenen Artefakte relativ umfangreich ist, kommen in ihm keine Gegenstände vor, die klar als frühneuzeitliche Militaria identifizierbar wären. Bei den meisten von ihnen ist lediglich eine grobe Datierung in den Zeitraum vom Hochmittelalter bis zur frühen Neuzeit möglich. Ferner wurde im Bereich des Vadkover Redan ein Sondierschnitt gelegt, um das ursprüngliche Profil von Wall und Graben zu erfassen. Die Innenkonstruktion des Walles hat dort keine regelmäßige Anordnung gezeigt. Als Anhaltspunkt für die Datierung der Entstehungszeit der Befestigung dienten zwei kleine Keramikfragmente und ein aus Holzkohle von der Wallbasis gewonnenes Radiokarbondatum. Den größten Beitrag zur Interpretation und Datierung der neu entdeckten Fundstellen lieferten jedoch die Archivquellen, obgleich wir uns hier ebefalls eher auf der Ebene indirekter Beweise bewegen. Die Befestigung wurde wahrscheinlich zu Beginn des Dreißigjährigen Krieges erbaut, als die kaiserliche und die Ständearmee in Südböhmen wiederholt in größeren und kleineren Scharmützeln aufeinandertrafen. Mit hoher Wahrscheinlichkeit handelte es sich um eine Sicherung der Stellungen der kaiserlichen Truppen, die im nahegelegenen Lhenice stationiert waren und ihnen eine kriegerische Auseinandersetzung mit der Ständegarnison aus Netolice drohte. Gemäß den fehlenden schriftlichen Nachrichten und archäologischen Quellen ist es jedoch im direkten Bereich der Befestigung zu keiner kriegerischen Begegnung gekommen. Diskutiert wird auch die Möglichkeit einer späteren Nutzung dieser strategischen Lage, was durch das Vorhandensein von subrezenten Militaria indiziert werden kann. 
Die Entstehung des vorliegenden Beitrags wurde von der Förderagentur der Südböhmischen Universität gefördert (Projekt Nr. 145/2016 H - Entwicklung von Studienprogrammen für Doktoranden der Phil. Fak. der Südböhmischen Universität - theoretische, methodische und editorische Aspekte der Programme der Geschichtswissenschaften und der Archäologie).

Mgr. Monika Konrádová, Archeologický ústav Filozofické fakulty Jihočeské univerzity v Českých Budějovicích, Branišovská 31a, 37005 České Budějovice, Česká republika,monicta@seznam.cz

Mgr. Václav Vondrovský, Archeologický ústav Filozofické fakulty Jihočeské univerzity v Českých Budějovicích, Branišovská 31a, 37005 České Budějovice, Česká republika,vaclav.vondrovsky@gmail.com

Mgr. Martin Pták, Archeologický ústav Filozofické fakulty Jihočeské univerzity v Českých Budějovicích, Branišovská 31a, 37005 České Budějovice, Česká republika, ptakma00@ff.jcu.cz

PhDr. Jan John, Ph.D., Archeologický ústav Filozofické fakulty Jihočeské univerzity v Českých Budějovicích, Branišovská 31a, 37005 České Budějovice, Česká republika,jjohn@ff.jcu.cz

Mgr. Jan Kocina, Archeologický ústav Filozofické fakulty Jihočeské univerzity v Českých Budějovicích, Branišovská 31a, 37005 České Budějovice, Česká republika,jankocina@gmail.com 
